\title{
REPORT ON THE SNOW SURVEY OF GREAT BRITAIN FOR THE SEASON $1947-48$
}

\author{
By E. L. Hawke and D. L. Champion
}

THE chief foundation of this report is the large quantity of data supplied to the Society by about I 40 observers who voluntarily keep day-to-day records of snowfall and snow cover at sites representing most of the main climatic regimes in England, Wales and Scotland. Through the courtesy of Sir Nelson Johnson, Director of the Meteorological Office, Air Ministry, and Dr. W. A. Harwood, Superintendent of the Meteorological Office at Edinburgh, these observations are supplemented by statistics relating to the state of the ground each morning at some 110 of the climatological stations which contribute returns to one or more of the official serial publications, The Daily Weather Report, The Weekly Weather Report and The Monthly Weather Report. In all, approximately 250 separate sets of records are thus available to the Society for analysis.

Our gratitude is accorded to every observer for his or her painstaking work during the season under review, and to Sir Nelson Johnson and Dr. Harwood for their collaboration in the Society's endeavours to advance knowledge of the distribution of British snowfall year by year in space and time.

$\begin{aligned} & \text { Metric Equivalents of Heights in FeEt } \\ & 100 \mathrm{ft} .=30.5 \mathrm{~m} . 2,500 \mathrm{ft} .=762.0 \mathrm{~m} . \\ & 500 \mathrm{ft} .=152.4 \mathrm{~m} . 3,000 \mathrm{ft} .=914.4 \mathrm{~m} . \\ & 1,000 \mathrm{ft} .=304.8 \mathrm{~m} . 3,500 \mathrm{ft} .=1,066.8 \mathrm{~m} . \\ & 1,500 \mathrm{ft} .=457.2 \mathrm{~m} . 4,000 \mathrm{ft} .=1,219.2 \mathrm{~m} . \\ & 2,000 \mathrm{ft} .=609.6 \mathrm{~m} .\end{aligned}$

In general, measurements of snow-depth cited in the Report refer to 0900 h. G.M.T., or thereabouts.

\section{SEPTEMBER 1947}

The month was unsettled and wet in the north-west, but dry in the south and east. Temperature was above normal in all districts and there was but little snowfall. According to The Times, the upper $\mathrm{I}, 000 \mathrm{ft}$. of Ben Nevis was covered with snow on the $29 \mathrm{th}$ and snowfalls were reported at 2,500 ft. on the Fannich Hills in Ross-shire on the 28th to 30th.

\section{OCTOBER 1947}

This month was exceptionally dry over Great Britain. In England and Wales it was the driest October since 1869 , with but 20 per cent of the normal precipitation. No snow was reported as lying anywhere, but slight falls were observed on three occasions at Baltasound in the Shetlands and on one occasion at Craibstone in Aberdeenshire.

\section{NOVEMBER 1947}

The weather of the month was relatively dry over England and Wales, but was wet in Scotland where rainfall averaged 39 per cent above normal. Mean temperature generally exceeded the normal, though there were wide fluctuations. The period from the 13 th to 19 th was cold, but a very warm, humid air stream raised temperatures by from $15^{\circ}$ to $25^{\circ} \mathrm{F}$. $\left(8.3^{\circ}\right.$ to $13.9^{\circ} \mathrm{C}$.) on the $20 t h$. Temperature fell rapidly again on the 24 th and cold conditions persisted until the end of the month.

Snowfall commenced in the north on the 13th, where it was reported at sea-level in the Orkneys and at Vementry in the Shetlands on the 14th. On the 13th "snow lying" was reported over most of the Scottish mountains down to levels between 2,000 ft. and 3,000 ft., and on Ben Wyvis, Rossshire, it persisted down to $1,000 \mathrm{ft}$. to the end of the month. On the Cuillins, Isle of Skye, snow was reported down to sea-level on the 15th to 18th. In the Lochaber district, Inverness-shire, 
snow lay continuously above $4,000 \mathrm{ft}$. throughout the month, with drifts up to $8 \mathrm{ft}$. $(2 \cdot 4 \mathrm{~m}$.) deep at $3,000 \mathrm{ft}$, and $18 \mathrm{in}$. $(45.7 \mathrm{~cm}$.) at valley level. At Tomintoul in Banffshire the snowfall reached 7 in. $(17.8 \mathrm{~cm}$.) in depth with drifts up to $6 \mathrm{ft}$. deep, causing much delay to road traffic. In Glenlivet in Banffshire at $1,050 \mathrm{ft}$. the snowfall was reported as the earliest for 20 years; a minimum temperature of $0^{\circ} \mathrm{F} .\left(-17.8^{\circ} \mathrm{C}\right.$.) was observed there on the $19 \mathrm{th}$.

At High Close in Westmorland snow lay down to $500 \mathrm{ft}$. on the $14 t h$, and at West Bromwich in Staffordshire it was 3.3 in. $(8.4 \mathrm{~cm}$.) deep on the $18 \mathrm{th}$. Most of Wales was well covered, 5 in. (12.7 cm.) being reported at Tairbull in Brecknockshire on the 18 th and drifts $5 \mathrm{ft}$. ( $1.5 \mathrm{~m}$.) deep near Ffair Rhos in Cardiganshire on the 19th. A very rapid thaw set in on the 20th removing nearly all the snow at all levels throughout the country. At Laggan considerable damage was caused to roads and bridges by the great rush of melt-water in the gullies.

During the second cold spell, from the $23 r d$ to the end of the month, snowfalls were reported from stations widely spread over the country but the cover was not continuously extensive. Apart from the mountains of Snowdonia where snow lay down to 2,000 $\mathrm{ft}$. Wales was almost snow-free as were the Shetlands and Outer Hebrides. Stenness in the Orkneys and Glen Brittle, Isle of Skye, had snow lying at sea-level; in the Sutherland, Grampian and Cairngorm Mountains a cover was reported down to levels between 2,000 ft. and 3,000 ft. and at the latter level at High Close.

At Whitchurch in Berwickshire snow was reported lying $3 \cdot 2$ in. $(8 \cdot 1 \mathrm{~cm}$.) deep at $800 \mathrm{ft}$. on the 30th. Snow was also reported as lying at $500 \mathrm{ft}$. at East Kirby, Nottinghamshire, on the 29 th and at Whipsnade in Bedfordshire from the 27th to 30th. Snowfalls were reported from places in Norfolk, Suffolk and Essex, but Kent was apparently snow-free. In the south-west, Lee Moor in Devonshire had a fall of 0.75 in. ( $1.9 \mathrm{~cm}$.) on the 26th; Princetown ( $\mathrm{I}, 359 \mathrm{ft}$.) on Dartmoor reported snow lying on the 26 th and 27 th.

\section{DECEMBER I947}

The month was abnormally mild and generally dry, precipitation being 83 per cent. of the normal over England and Wales and $5^{8}$ per cent. over Scotland. Apart from showers during the first five days in the north, there was little snowfall until the last three days of the month. Blizzard conditions prevailed in parts of Scotland on the $29 \mathrm{th}$.

With the accumulation of snow at the end of November the cover became 7 in. $(17.8 \mathrm{~cm}$.) deep at Auchintoul in Sutherlandshire from December 1 st to 6 th at $420 \mathrm{ft}$. The heaviest snowfalls of the month occurred throughout the country on the 29 th and $30 t h$. On the 29 th snow lay 6 in. (1 $5 \cdot 2 \mathrm{~cm}$.) deep at Sligachan, Isle of Skye and at Donside in Aberdeenshire. At 3,000 ft. on the Cuillins the cover was $4 \mathrm{ft}$. $(1 \cdot 2 \mathrm{~m}$.) deep. On the same day falls of $\mathrm{I}$ in. $(2.5 \mathrm{~cm}$.) were noted at Stenness in the Orkneys, $2 \cdot 5$ in. $(6.3 \mathrm{~cm}$.) at Fyvie Castle in Aberdeenshire, and on the 30 th 0.5 in. $(1 \cdot 3 \mathrm{~cm}$.) in North Uist, Outer Hebrides.

During this period falls of 5 in. (12.7 cm.) or more were noted at several places in Lancashire, Shropshire, Worcestershire and Denbighshire. Snow cover 2 in. $(5 \cdot 1 \mathrm{~cm}$.) deep was observed as far south as Bovinger, Essex, and 0.3 in. $(0.8 \mathrm{~cm}$.) in the south-west at East Anstey in Devonshire on the 30 th.

D. L. C.

\section{JANUARY I948}

Extremely unsettled and stormy weather characterized the opening month of 1948. Over England and Wales as a whole it was the wettest January on record, with 234 per cent of the average precipitation, while in Scotland the corresponding percentage of 162 had not been exceeded or equalled in January since 1928 . Numerous cyclonic systems and troughs of low pressure passed from the Atlantic directly across the British Isles; the polar air associated with these repeatedly engulfed our northern districts, though it seldom penetrated to the south. As a result the month 
ranked as a cold one in Scotland, but was milder than usual in nearly all parts of England and Wales and notably mild in the southernmost English counties. At and above the $1,000 \mathrm{ft}$. level in central and northern Scotland the mean temperature was a little below freezing point, whereas along the shores of the English Channel it ranged commonly from $44^{\circ}$ to $47^{\circ} \mathrm{F}$. $\left(6 \cdot 7^{\circ}\right.$ to $8 \cdot 3^{\circ} \mathrm{C}$.). This steep thermal gradient from south to north was reflected by a more than usually pronounced rise in the amount and frequency of snow with increasing latitude. Except from the 2 nd to 4 th and on the 31st snowfalls occurred daily in the northern half of Britain, and, though rarely heavy, they were often widespread. Among individual stations snow was recorded on 17 days at Glenlivet ( $1,050 \mathrm{ft}$. ), at Carluke ( $534 \mathrm{ft}$.), in Lanarkshire and at Eskdalemuir ( $794 \mathrm{ft}$.) in Dumfries-shire; on I6 days at Balmoral ( $927 \mathrm{ft}$.) in Aberdeenshire and at Bellingham ( $849 \mathrm{ft}$.), in Northumberland. On the Cuillins snow lay at least $12 \mathrm{in}$. $(30.5 \mathrm{~cm}$.) deep below the $3,000 \mathrm{ft}$. level throughout the month and became 24 in. $(61 \mathrm{~cm}$.) deep from the 16 th to $25 \mathrm{th}$. A continuous cover was also reported below 2,000 ft. on the Fannich Hills and Ben Wyvis in Ross and Cromarty. At about the 1,000 ft. level, Braemar in Aberdeenshire had 28 days of snow lying, Dalwhinnie in Inverness-shire 27 days and Balmoral 26 days. At $608 \mathrm{ft}$. Logie Coldstone in Aberdeenshire was exceptional with 26 days; there were $\mathrm{I} 9$ at Glenlivet, 18 at West Linton ( $820 \mathrm{ft}$.) in Peebles-shire and $\mathrm{I} 7$ at Balerno (75o ft.) in Midlathian. None of the month's individual snowfalls could be classed as out of the ordinary. Few places below $1,000 \mathrm{ft}$. reported a maximum depth of cover exceeding $8 \mathrm{in} .\left(20^{\circ} 3 \mathrm{~cm}\right.$.) after the chief falls, which came generally on the 9 th to 10 th and 17 th to $23 \mathrm{rd}$. At levels rather above $\mathrm{I}, 000 \mathrm{ft}$. the neighbourhood of Blaircreich in Perthshire was outstanding with over $\mathrm{I} 2 \mathrm{in}$. $(30.5 \mathrm{~cm}$.) of snow lying each morning from the 10 th to about the $25 \mathrm{th}$; drifts there were then commonly from 5 to $6 \mathrm{ft}$. ( $\mathrm{I} \cdot 5$ to $\mathrm{I} \cdot 8 \mathrm{~m}$.) and "very much deeper higher up." Outside Scotland and the northernmost counties of England instances of as much as a 6 in. $(15.2 \mathrm{~cm}$.) cover were confined to upland stations in Yorkshire and North Wales. Chew Mount ( $1,600 \mathrm{ft}$.) in Yorkshire reported 6 in. $(15.2 \mathrm{~cm}$.) on the $22 \mathrm{nd}$ and $23 \mathrm{rd}$ and Nantyr (r,080 ft.) in Denbighshire the same depth on the 6th. In central and southern England and South Wales there was local snow on 12 days between the 6 th and 24th; as a rule it took the form of light showers and average depths of as much as $I$ in. $(2.5 \mathrm{~cm}$.) appear to have been mainly restricted to $750 \mathrm{ft}$. and above. Some low-lying parts of East Anglia, however, had about $\mathbf{I}$ in. for a few hours early on the 20th. At a large majority of stations in the far south of England January passed entirely without snow or sleet.

\section{February $194^{8}$}

The rough and unsettled conditions of January persisted throughout the first half of this month. In general the weather was mild for the season and, except on the uplands in the north, appreciable snowfalls were rare until the $15 \mathrm{th}$ : showers of snow or sleet were, however, fairly widespread in Scotland and the northern and north midland counties of England from the 2 nd to $8 t h$ and again on the $12 t h$. After the $15 t h$ high barometric pressure became established towards the north and north-east of Britain and air drawn from the interior of Europe led to the prevalence of predominantly low temperatures from the 16th to $27 \mathrm{th}$. During this period Scotland was mostly under a dry anticyclonic regime, but troughs of low pressure brought frequent snow to England and Wales, particularly from the 19 th to $23 \mathrm{rd}$. At that time intense cold ruled in southern districts; Lympne, Kent, had day maxima of $22^{\circ} \mathrm{F} .\left(-5 \cdot 6^{\circ} \mathrm{C}\right.$ ) and $24^{\circ} \mathrm{F} .\left(-4.4^{\circ} \mathrm{C}\right.$.) on the 20 th and 21 st respectively, and on the night of the $21 s t-22 n d$ there were screen minima of $5^{\circ} \mathrm{F}$. (-I $5.0^{\circ} \mathrm{C}$.) at East Malling, Kent, $7^{\circ} \mathrm{F}$. (-r $3.9^{\circ} \mathrm{C}$ ) at Tunbridge Wells, Kent, and $8^{\circ} \mathrm{F}$. (- $333^{\circ} \mathrm{C}$ ) at Milford in Surrey. These low nocturnal readings resulted from strong radiation with a temporary clearance of the sky after a snowstorm which was described by several observers as rivalling any experienced at their stations during the exceptionally severe winter of 1946-47. On the morning of the $22 n d$ the average depth of the snow cover reached 14 in. $\left(35^{.6} \mathrm{~cm}\right.$.) at Biggin Hill $(596 \mathrm{ft}$.) 
in Kent, 12 in. $\left(30.5 \mathrm{~cm}\right.$.) at Downe $\left(560 \mathrm{ft}\right.$.) in Kent and Bovinger (250 ft.) in Essex, $1 \mathrm{I} \frac{1}{2}$ in. $(29.2 \mathrm{~cm}$.) at Wilmington (212 ft.) in Kent, ro in. $(25.4 \mathrm{~cm}$.) at Croydon $(217 \mathrm{ft}$.) in Surrey and 9 in. $(22.9 \mathrm{~cm}$.) at Bromley, Lympne and West Malling in Kent and at Bexhill and at Eastbourne in Sussex. Strong squally easterly winds produced heavy drifting in exposed districts-to as much as $8 \mathrm{ft}$. $(2.4 \mathrm{~m}$.) locally-and a number of roads were impassable for two or three days. Although generally of less intensity elsewhere than in the extreme south-east, this snowfall was very widely distributed; according to reports received by the Automobile Association it affected 43 counties in England and Wales. Even in the Scilly Isles, St. Mary's had a 2 in. $\left(5^{.1} \mathrm{~cm}\right.$.) cover on the morning of the 22nd. Upland roads in central Wales and Shropshire were blocked by drifts up to $8 \mathrm{ft}$. $(2.4 \mathrm{~m}$.). There were average depths exceeding 6 in. $(15.2 \mathrm{~cm}$.) at Buxton $(1, \infty) 7 \mathrm{ft}$.) in Derbyshire from the 21st to 23rd; of 5 in. (12.7 cm.) at East Kirby and 4 in. (10.2 cm.) at Aberglanherin $(1,250 \mathrm{ft}$.) and Colva $(1,265 \mathrm{ft}$.) in Radnorshire on the 21 st to $23 \mathrm{rd}$. Observers in the Scottish lowlands regarded February 1948 as notably free from substantial snowfalls. Below 1,200 $\mathrm{ft}$. few places reported a maximum depth exceeding $6 \mathrm{in.}\left(15^{\circ} \mathrm{cm}\right.$.) at any time. On the higher mountains of Scotland the cover laid down in January persisted throughout the ensuing month: this extended to below 2,000 ft. on the Fannich Hills and to below 2,500 ft. on Ben Wyvis. In Skye the Cuillins were seen to be snow-capped every day except the 15 th and $28 t h$ to $29 t h$, when bad visibility prevented observation.

\section{MARCH 1948}

This was an exceptionally genial month, the mean temperature over Britain as a whole exceeding the average by nearly $5^{\circ} \mathrm{F} .\left(2 \cdot 8^{\circ} \mathrm{C}\right.$.). Almost all districts apart from western Scotland had deficient precipitation and a notable abundance of sunshine. In England the only snowfalls reported were slight ones at levels above $750 \mathrm{ft}$. in Northumberland, Westmorland, Yorkshire and Lancashire-chiefly from the 16th to 18th. Locally in the extreme south-east, however, drifts left over from February survived until March 3rd or 4th. In Wales minor falls visited the Carnedd range on the 18th: on the 29th and 30th many of the Caernarvonshire and Merionethshire mountains lay under a thin cover and the Glamorganshire heights were also capped. At Aberglanherin the February drifts were still $3 \frac{1}{2} \mathrm{ft} .(\mathrm{I} \cdot \mathrm{I} \mathrm{m}$.) deep on the 1 st and did not disappear until the $8 t h$. In Scotland the freedom from much snow at low and moderate altitudes was a subject of general comment by observers: trifling falls occurred on at least six days, mostly around mid-month, but depths of as much as 2 in. $(5.1 \mathrm{~cm}$.) were rarely reached under $1,000 \mathrm{ft}$. At higher levels, the Fannich Hills bore a continuous cover throughout March to below 2,500 $\mathrm{ft}$. and Ben Wyvis to below 3,000 ft., the snow-line on the latter mountain descending to within $500 \mathrm{ft}$. of sea-level on the 16th. In Skye, some of the mountains near Sligachan were coated at 3,000 $\mathrm{ft}$. from the 1 st to 8 th, 16 th to 26 th and 29 th to 31 st, but except from the 1 st to 4 th the reported depth never exceeded 3 in. $(7.6 \mathrm{~cm}$.).

\section{APRIL 1948}

"A warm and generally sunny month" was the summarized description of April in the official Monthly Weather Report. Over Britain as a whole the mean temperature exceeded the average by $2.5^{\circ} \mathrm{F}$. ( $1 \cdot 4^{\circ} \mathrm{C}$.). Snow occurred rather commonly during the first ten and the last three days, but except above $75^{\circ} \mathrm{ft}$. the falls consisted mainly of light showers. The Fannich Hills remained covered to below 2,500 ft. all through the month, Ben Wyvis to below 3,000 ft. from the 1st to 18th, the Cairngorms and some of the Westmorland, Caernarvonshire and Merionethshire mountains to below 3,000 ft. from the 1 st to $12 \mathrm{th}$. Here and there in these areas the snow-line came down to within 1,000 ft. of sea-level at intervals between the 4th and $9 t h$. From the 1 st to 5 th there were drifts up to $\mathrm{r} 8 \mathrm{in}$. $\left(45^{\circ} 7 \mathrm{~cm}\right.$.) deep on Merionethshire heights. Snowflakes of exceptional size were 
observed in parts of Wales and the western English midlands on the 4th; their diameter ranged upwards to $2 \frac{1}{4}$ in. $(5.7 \mathrm{~cm}$.) at West Bromwich $(537 \mathrm{ft}$.) in Staffordshire and $2 \mathrm{~m} .(5.1 \mathrm{~cm}$.) at Crickhowell (210 ft.) in Brecknockshire. From the 27th onwards shallow depressions moving south-eastward across Britain brought widespread snow: a cover formed in numerous upland regions, drifting to 18 in. $(45.7 \mathrm{~cm}$.) on the upper Merionethshire peaks. Locally there were appreciable falls even at low levels in southern England. On the afternoon of the 30 th a heavy squall of snow and hail put down a layer 4 in. $(10.3 \mathrm{~cm}$.) deep over an area estimated at one square mile near Uffculme in Devonshire.

\section{May 1948}

Though notable for its plentiful sunshine and differing little on the whole from the normal temperature, this month was by no means free from wintry weather. From the 1st to 4th and again from the 21st to 28th upland snowfalls were widely distributed in Scotland, Wales and northern England. At the 750-I,000 ft. level they occurred on eight days at Glenlivet and Bellingham. The observer at the former station reported that, according to local accounts, the falls between the $22 n d$ and 28 th had not been matched there so late in the spring since 1907. On the 1 st and 2nd snow showers penetrated as far south as Dartmoor, the Cotswolds and the Chilterns. For a period of two or three days from the 23 rd a cover seems to have been fairly general on the higher mountains in both North and South Wales; even at $1,250 \mathrm{ft}$. Aberglanherin had 3 in. $(7.6 \mathrm{~cm}$.) lying from the $23 r d$ to $25 t h$. In Scotland the Fannich Hills retained their winter coating until the 14th; during the warm spell from the 15 th to 21 st only drifts held out, but from the $22 n d$ onwards a complete cover was renewed by frequent falls of fresh snow. 'The upper reaches of Ben Wyvis were reported clear from the 5 th to 21st, and covered again from the $22 n d$ to $30 t h$. In North Uist the first snow of 1948 came in the form of sleet showers on May 12.

\section{SUMMER, I 948}

In November 1948 the Director of the Snow Survey (E. L. H.) had an opportunity to consult the $\log$ book placed by the British Glaciological Society in the hut on Ben Nevis for the use of visitors wishing to record their meteorological observations. It appeared that, although the $1947-48$ winter had brought less snow than usual to the mountain as to Scotland as a whole, there were very heavy falls towards the close of March and the accumulations in some of the gullies were exceptionally great during the first week of April. The spring and summer months were mostly cold and melting was therefore slow. On August 19th about a dozen patches of snow were found between the Carn Mor Dearg ridge on the east and Green Gully on the west. An entry made on September 13th stated that many of these patches were still surviving, one of them being then $150 \mathrm{ft}$. by $100 \mathrm{ft} .(45 \times 30 \mathrm{~m}$.) in area and about $6 \mathrm{ft} .(1.8 \mathrm{~m}$.) decp, and another (no measurements given) "considerably bigger." The snow on September 13th was reported to be so compact that steps could only be kicked in it with difficulty.

\section{SUMMARY}

Contrasting strongly with its immediate forerunner, the $1947^{-48}$ season was in general one of light or moderate snowfall over Great Britain. January brought frequent and widespread snow to Scotland and falls which affected most of England and Wales during the second half of February were in some south-eastern districts heavy enough to compare with any experienced there during the exceptionally severe winter of $1946-47$. Towards the close of May, snow, said to have been the latest since 1907 , occurred on several days at about $\mathrm{I}, 000 \mathrm{ft}$. in the Glenlivet region of Banffshire. Locally in the Devon-Cornwall peninsula (at Dawlish for example) the entire season was reported to have passed without either snow or sleet. There was complete freedom from cover in 
various areas of south-west England, west Wales and the Western Isles of Scotland. Among the contributing stations at levels below I, $500 \mathrm{ft}$. the maximum frequencies of days with snow or sleet from September to June appear to have been $5^{8}$ at Glenlivet and $5^{2}$ at Braemar on Upper Dee-side. At St. Mary's in the Scilly Isles the morning of February 22nd, 1948 was the ninth occasion since fanuary 1st, 1947 on which snow was reported lying. During the 26 years 1920-26 and $1928-46$ (no data being available for 1927 ) the aggregate number of such mornings was seven.

E. L. H.

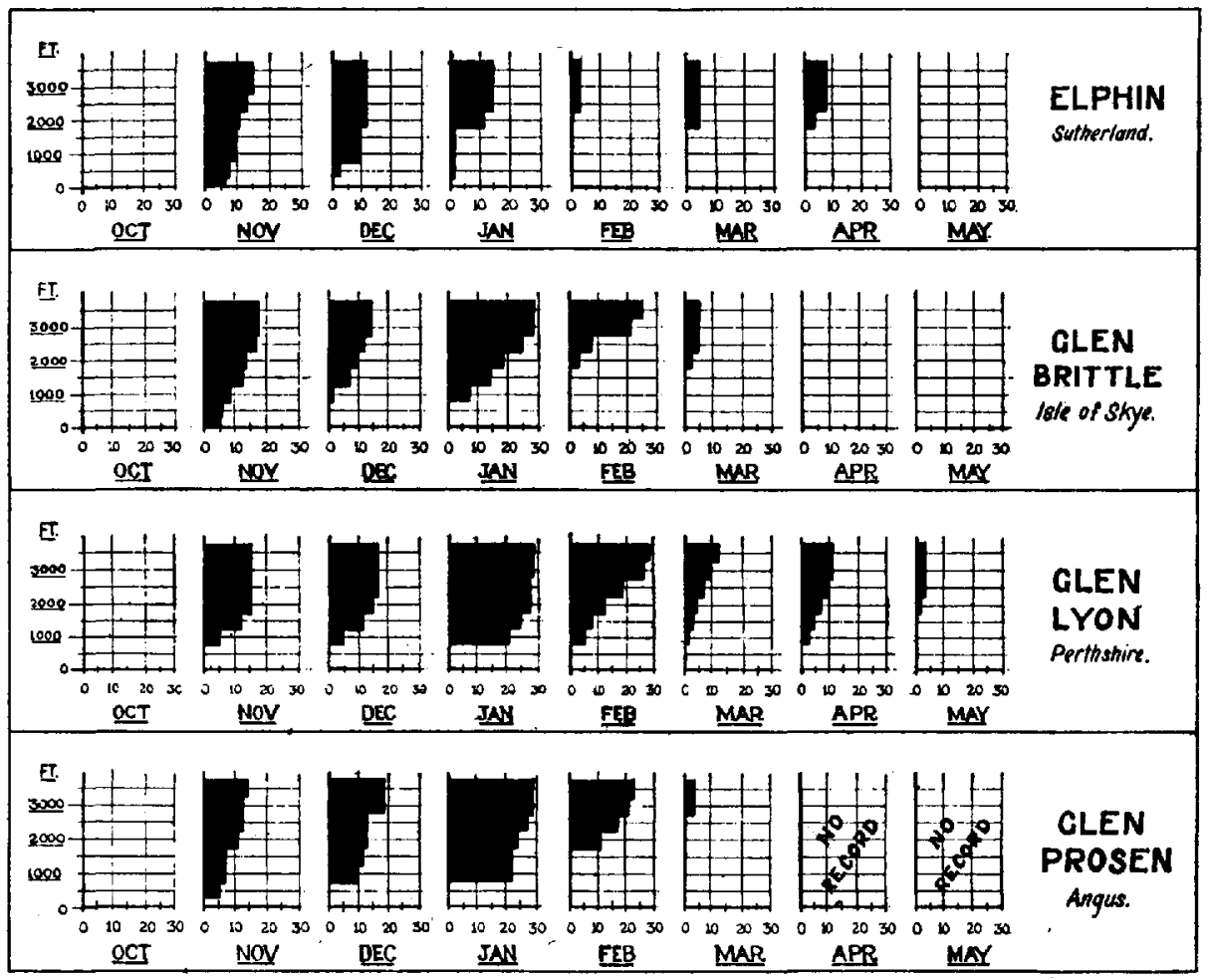

\section{NOTE ON DURATION OF SNOW COVER ON BRITISH MOUNTAINS}

Although the season October to March was far less severe than in the previous year, there was more snow on the mountains of Britain during November; and, whereas in May 1947 there was no appreciable snow on the mountains, in May I948 "snow lying" was reported on the higher mountain levels as far south as Tairbull in Brecknockshire.

Graphs showing the distribution of snow cover, relative to height on British mountains, are shown here, the basis for these diagrams being as set out on p. 13I of the 1946-47 Report.* Data are included from two additional stations, viz. Glen Prosen in Angus and Llanfrothen in Merionethshire.

At Elphin in Sutherlandshire the duration of snow cover was longest at all levels in November,

- Fournal of Glaciology, Vol. I, No. 3, 1948. 
reaching $\mathrm{I}_{5}$ days at the $3,000 \mathrm{ft}$. level. No snow was reported to be lying at any level in October or May. At Glen Brittle in the Cuillins snow lay for 27 days at and above the 3,000 ft. level in January and for 25 days at 3,500 ft. in February. No snow was reported as lying at any level in October, April or May.

In Glen Lyon "snow lying" was reported at 2,000 ft. or above in every month except October, the duration exceeding 20 days at $\mathrm{I}, 000 \mathrm{ft}$. in January; down to $3,500 \mathrm{ft}$. snow lay continuously throughout February. In Glen Prosen the duration of snow cover relative to height was very

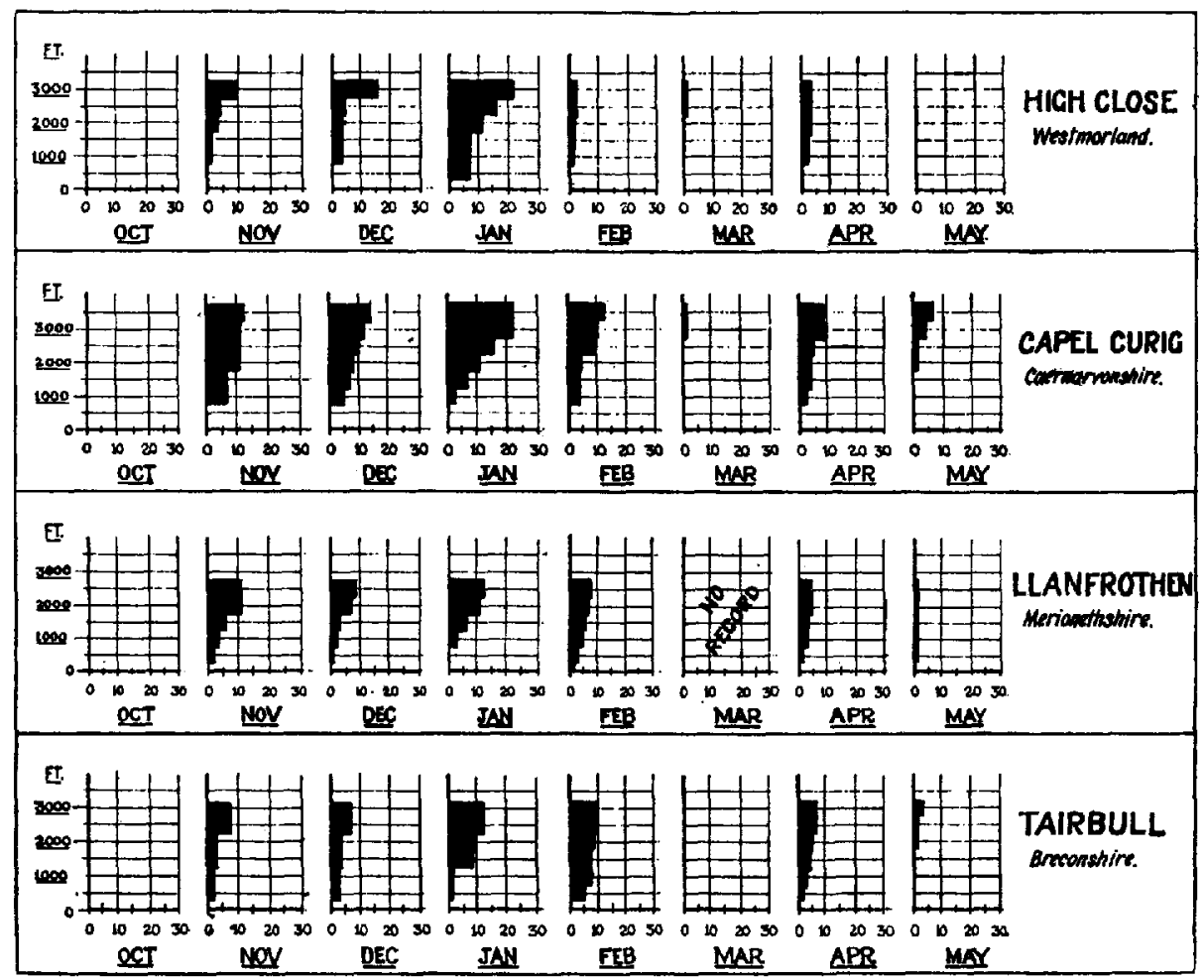

similar to that found in Glen Lyon during the months October to February, but did not exceed 23 days at 3,500 ft. in the latter month.

At High Close in the Lake District no snow cover was observed in October or May, and, except in January, the duration below 2,000 ft. did not exceed five days in any month. At this station the maximum duration occurred in January at all levels, reaching 22 days at 3,000 $\mathrm{ft}$.

At Capel Curig, on the Snowdon range, "snow lying" at or above 3,000 ft. was reported in every month except October, and in May the duration of the cover down to 2,000 $\mathrm{ft}$. exceeded that recorded at any other station, with 6 days at the highest levels. In January the duration exceeded 20 days down to $3,000 \mathrm{ft}$.

At Llanfrothen snow cover was reported at all levels during February, though at no height did it last for ten days. No snow lay at any level in October. "Snow lying" was reported from Tairbull in all months except October and March, the distribution relative to height being similar to that at Llanfrothen. 
Data from six of the above stations are summarized graphically in Fig. I (below) by curves showing the total duration of snow cover throughout the season. As in the 1946-47 season, the duration on the Grampians around Glen Lyon exceeded that at all the other stations, with a maximum of I 3 days at $3,500 \mathrm{ft}$. It is of particular interest to note that above $2,500 \mathrm{ft}$. the duration of snow cover on Snowdon (Capel Curig) considerably exceeded that on the Sutherlandshire mountains at Elphin.

D. L. C.

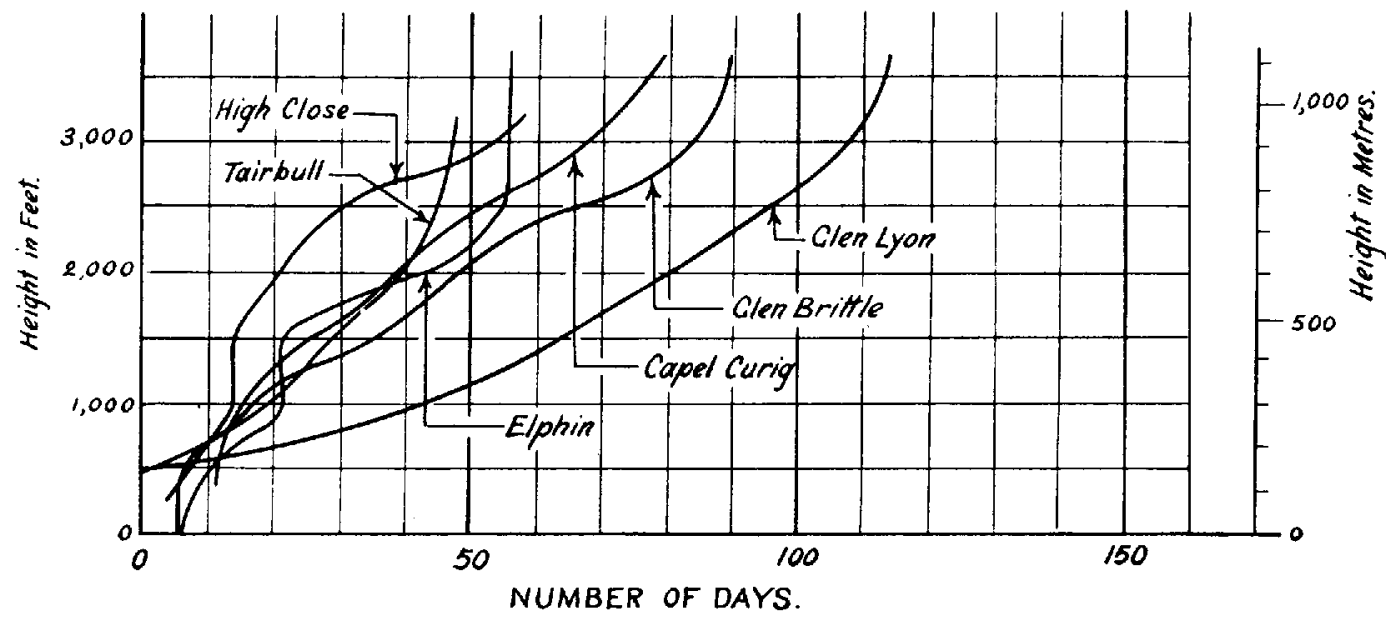

Fig I. Curves showing total duration of snow cover for winter $1947-48$ at six stations in Great Britain.

\section{A F ILM OF GLACIER FLOW}

WhEN the Jungfraujoch Research Party of $193^{8}$ was working on the Great Aletsch Glacier it became apparent that a film showing speeded-up motion of the ice would tell us'a great deal about the vexed problem of glacier flow.

The idea, however, turned out not to be a new one, for I found that $A$. de Quervain had made a film at the end of the Upper Grindelwald Glacier as far back as I9r2. Recently I have had the opportunity of seeing this film in London (through the courtesy of Dr. P. L. Mercanton) and at Oslo. It is a creditable achievement considering the apparatus available at the time. The time has now come, however, when, with modern apparatus and automatic shutters and diaphragms, a contribution of immense value could be made to glacial science. The undertaking will be no small one and shots in several parts of a glacier and at different seasons will be necessary.

G. Seligman 